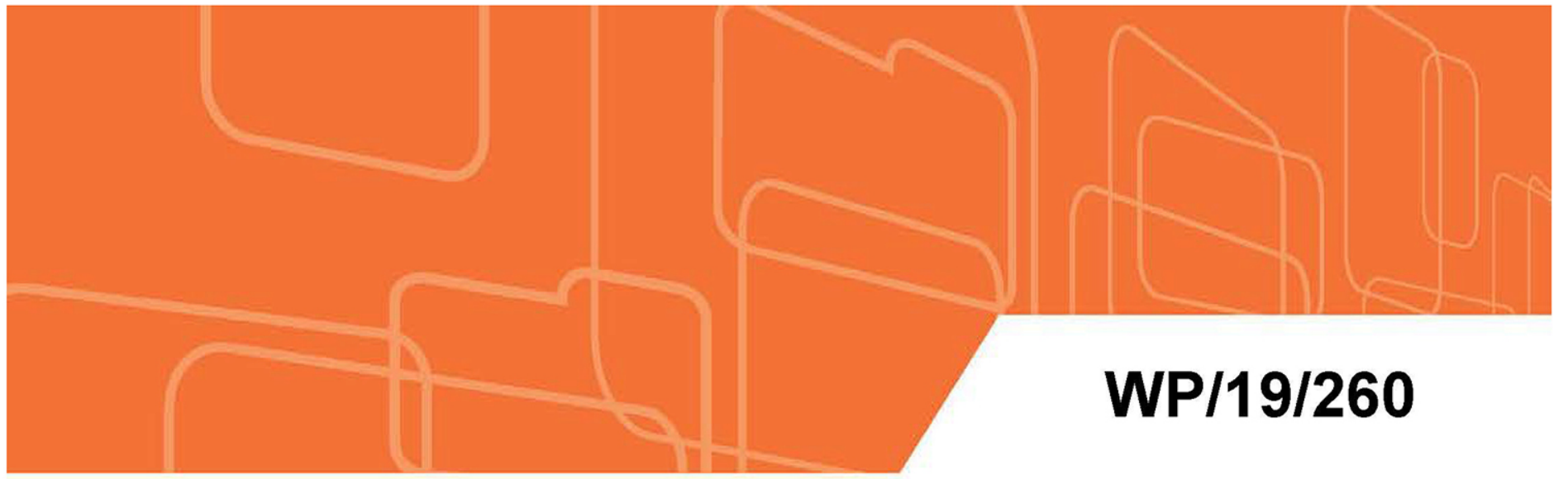

IMF Working Paper

\title{
Productivity and Tax Evasion
}

by Era Dabla-Norris, Mark Gradstein, Fedor Miryugin, and Florian Misch 


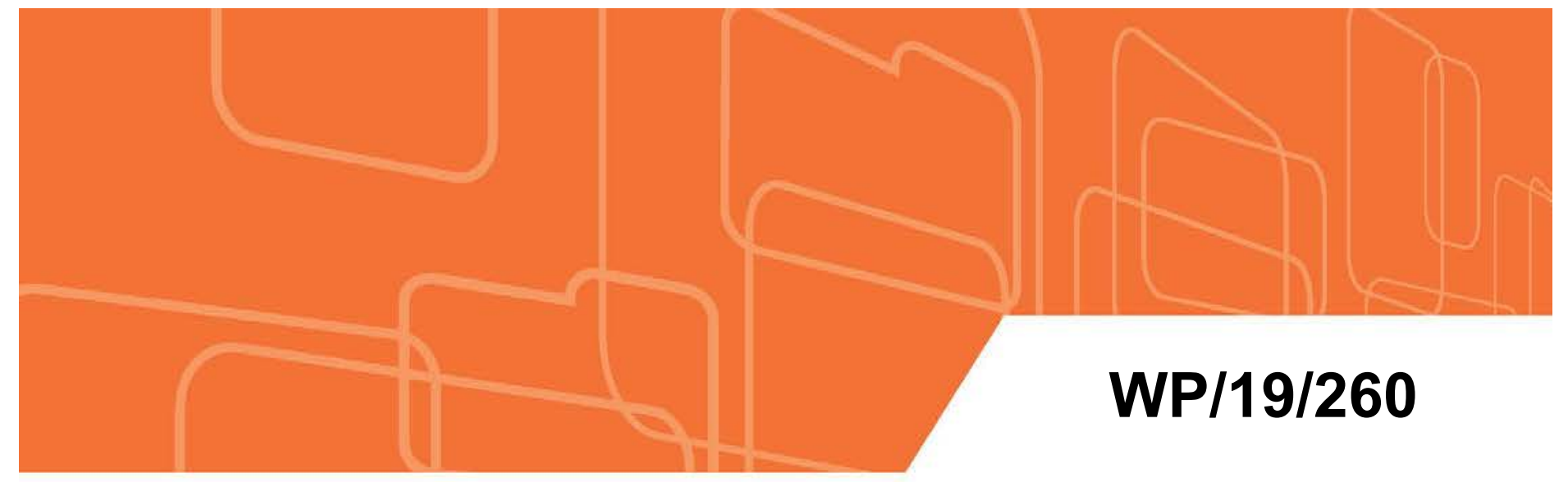

\section{IMF Working Paper}

\section{Productivity and Tax Evasion}

by Era Dabla-Norris, Mark Gradstein, Fedor Miryugin, and Florian Misch

I N T E R N A T I O N A L M O N E T A R Y FU N D 


\title{
IMF Working Paper
}

Fiscal Affairs Department

\section{Productivity and Tax Evasion*}

\section{Prepared by Era Dabla-Norris, Mark Gradstein, Fedor Miryugin, and Florian Misch \\ Authorized for distribution by Era Dabla-Norris}

November 2019

IMF Working Papers describe research in progress by the author(s) and are published to elicit comments and to encourage debate. The views expressed in IMF Working Papers are those of the author(s) and do not necessarily represent the views of the IMF, its Executive Board, or IMF management.

\begin{abstract}
The extent of tax compliance has important implications for revenue yield, efficiency and the fairness of any tax system. Tax evasion undermines revenue collection, distorts competition, and undermines a country's development prospects. In this paper, we investigate whether higher productivity causally leads to lower tax evasion. We first present stylized facts consistent with this view and develop a model that illustrates one potential transmission channel. Second, we test the model predictions at the firm level using the self-reported share of declared income as proxy for tax evasion for a large sample of emerging and developing economies. Our results suggests that productivity improvements by firms can lead to lower tax evasion.
\end{abstract}

JEL Classification Numbers: D20, H26, O47

Keywords: Economic Development, Firm Productivity, Tax Evasion

Author's E-Mail Address: edablanorris@imf.org, grade@bgu.ac.il, mifegor@umich.edu, fmisch@imf.org

* We thank John Ricco for research assistance on an earlier version of the paper and Olusegun Akanbi, Federico Diez, Izabela Karpowicz, Nir Klein, and Cian Ruane for comments. The views expressed herein are those of the authors and should not be attributed to the International Monetary Fund, its Executive Board, or its management. 


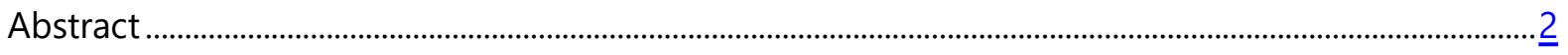

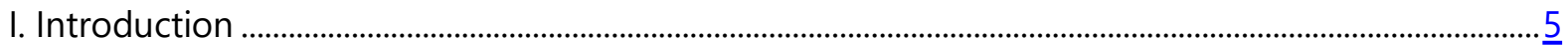

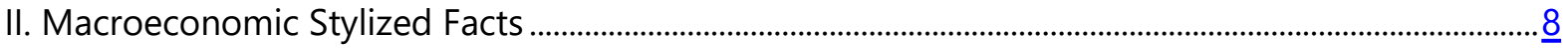

III. Theoretical Framework ...........................................................................................................................

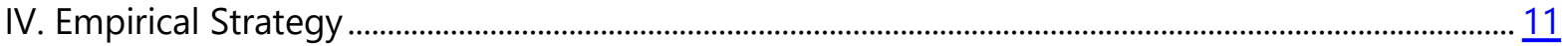

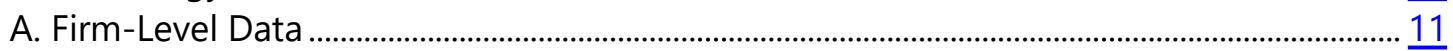

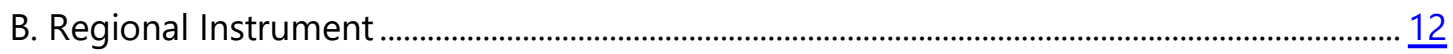

C. International Instrument ......................................................................................................

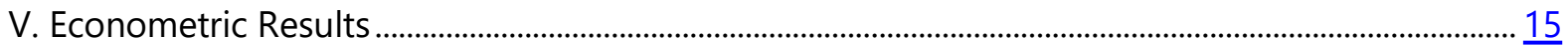

A. OLS ..... -

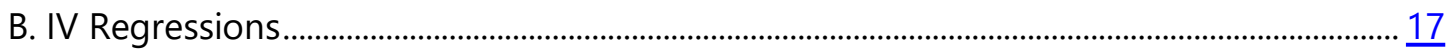

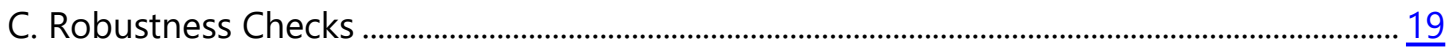

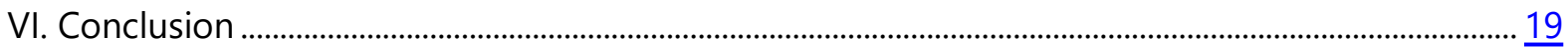

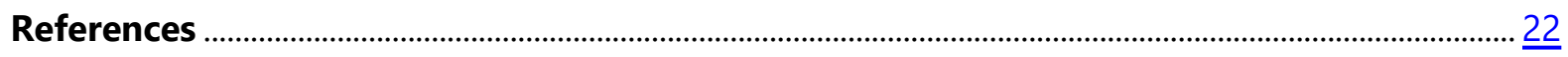

\section{Appendix}

Appendix 1. Macroeconomic Stylized Facts: Details of the Estimation and Robustness Checks.... $\underline{25}$

Appendix 2. Derivations and Model Extension................................................................................. 29

Appendix 3. Variable Definitions and Descriptive Statistics ..............................................................

Appendix 4. Regional and International Instrument Construction .......................................................... $\frac{31}{33}$

Appendix 5. First-Stage Regressions ...................................................................................................... 33

\section{Tables}

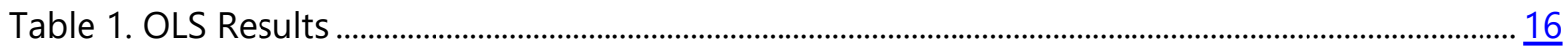

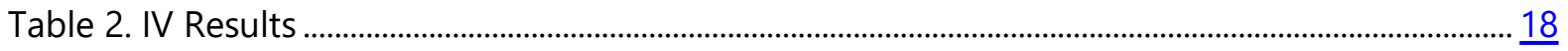

Table 3. IV Robustness Checks ................................................................................................................. 21

Table Appendix 1. 1. Variable definition...................................................................................................... 26

Table Appendix 1. 2. Baseline specifications........................................................................................... 27

Table Appendix 1. 3. Robustness checks.............................................................................................. 28

Table Appendix 1. 4. Robustness checks with interaction terms ………………………………………...

Table Appendix 3. 1. Variables, Definitions and Units............................................................................. 30

Table Appendix 3. 2. Descriptive Statistics of IV Baseline Sample ............................................................. 
Table Appendix 4. 1. Regional Instruments (Main Sample)

$\frac{31}{32}$

Table Appendix 4. 2. Commodity Country Pairs (IV Baseline Sample).

Table Appendix 5. 1. First Stage of Table 2

$\underline{33}$

Table Appendix 5. 2. First Stage of Table 3

Figure

Figure 1. OLS and 2-stage LS results 


\section{INTRODUCTION}

Low tax compliance by firms in many emerging and developing economies raises concerns from a public policy perspective. This weakens aggregate tax revenue mobilization, adversely impacts the fairness of the tax system, and is associated with poor development prospects. ${ }^{1}$ There are two relatively undisputed stylized facts on the relationship between tax evasion and productivity: first, tax evasion is higher in poor countries, and second, tax-evading firms tend to be less productive. ${ }^{2}$ The objective of this paper is to re-visit the link between tax evasion and productivity.

Evidence suggests that productivity gaps between firms that comply with existing taxes and regulations and those which do not are significant, ranging between 25 to 50 percent or more (Amin et al., 2019, Faynzylber, 2011; Busso et al., 2012). These large gaps can translate into low economy-wide productivity and growth if, by not complying with existing taxes and regulations, firms enjoy a potentially large implicit subsidy that allows them to stay in business despite low productivity, or to expand their market share at the expense of more productive firms (see, for example, Farrell, 2004; Bobbio 2016). At the macroeconomic level, Loayza and Rigolini (2006) and La Porta and Shleifer (2014) show that informality, proxied by the share of self-employment, is larger in countries that have a lower GDP per capita. ${ }^{3}$

Studies also find that tax evasion and informality are associated with lower aggregate income levels and productivity (see Dabla-Norris and Feltenstein, 2003, Loayza, 1996, and Sarte, 2000). There are several reasons why this could be the case. First, tax evasion undermines public revenue, which in turn can lower productive public spending. Second, large-scale tax leads to more credit rationing by the banking system, resulting in lower economy-wide investment. Third,

\footnotetext{
${ }^{1}$ A large literature in development economics has studied duality and non-compliance with existing taxes and regulations (commonly denoted as informality) as a source of low productivity in poor countries (Lewis, 1954; Rauch, 1991; La Porta and Shleifer, 2014). One challenge of the empirical literature on tax compliance is that by definition, tax evasion is hidden so that it is difficult to obtain precise measures (Kundt et al., 2017; Slemrod and Weber, 2012).

${ }^{2}$ Other studies argue that avoiding onerous taxes and regulations may also confer firms with greater flexibility in their employment and production decision, allowing them to operate more efficiently (Almeida and Carneiro 2009).

3 There are many conceptual and statistical definitions of formality and informality, but the Kanbur and Keen's (2015) terminology of distinguishing between evaders, avoiders, and outsiders is pertinent for our paper. Evaders, the focus of this paper, are firms covered by the law but do not comply. Avoiders are firms that adjust to put themselves outside the remit of the law, while outsiders are those simply not covered by the existing legislation (e.g., micro-enterprises). See also Kanbur (2017).
}

CInternational Monetary Fund. Not for Redistribution 
tax evading firms can afford to be less productive while still taking market share from more productive firms, thereby undermining aggregate productivity.

On the other hand, it may be the case that the more productive firms choose to comply with taxes and regulations. This suggests that the direction of causality is not clear cut. For instance, Fajnzylber et al. (2011), based on a review of other papers, conclude that more productive firms may be the ones who require the benefits associated with formality. The correlation of formality with productivity is thus potentially driven by the firms' underlying characteristics. Similarly, more successful businesses are more likely to be detected by tax administrations, especially as they grow, which may lead them to improve tax compliance to avoid paying fines and/or bribes. ${ }^{4}$ Links to the financial sector may also increase incentives for tax compliance by productive firms due to information disclosure requirements (Gordon and Li, 2009).

In this paper, we re-examine the link between tax evasion at the firm level-encompassing firms that are registered with the tax authority but underreport their sales for tax purposes-and productivity. Specifically, we explore the causality link from productivity to tax evasion, whereby an increase in firm productivity leads to a higher share of sales reported for tax purposes. We motivate our analysis at the aggregate level by relying on a commonly-used proxy for tax noncompliance, namely the extent of self-employment in an economy. Feldman and Slemrod (2007) note that income from self-employment tends to be underreported relative to other sources of income even in the advanced economies (see also Kleven, 2011). We show that an increase in per capita income has a causal impact on the share of self-employment, complementing the stylized facts in La Porta and Shleifer (2014). In particular, instrumenting for per capita GDP, in a crosscountry panel we find that economic development reduces the share of self-employment in an economy. We view this as an indication of a potential causal effect productivity may have on tax compliance.

To set the stage for our empirical investigation, we present a simple model where firms sort themselves into whether they comply with taxation or whether they are fully non-compliant (i.e., informal). The model is built on by now well-established foundations (see Lucas, 1978, Rauch, 1991, Dabla-Norris, Gradstein, and Inchauste 2008; Kanbur 2017). In the resulting dual economy equilibrium, high productivity firms end up in the former, and low productivity firms end up in the latter. The reason for this is that the more productive a firm, the larger is the benefit of operating formally for a given level of associated costs, some of which are essentially fixed. Similarly, evading taxes altogether is relatively more detrimental for such firms relative to less

\footnotetext{
${ }^{4}$ Alm et al. (2016) show how the potential for bribery of tax officials affect's a firm's tax evasion decisions. Kleven et. al (2016) develop a model which shows that firms' use of business records increases as it hires more employees. They show that the government may be able to enforce higher tax compliance even in the presence of a low threat of audit due to the increased ease of whistle-blowing as the firm grows.
} 
productive ones, as this entails potential loss of access to publicly provided services and finance, in addition to penalties if caught engaging in tax evasion.

Our empirical analysis is conducted at the firm level, using data from the World Bank Enterprise Surveys for a large cross-section. The surveys contain information on the percentage of sales firms report for tax purposes for 47 emerging and developing economies. To disentangle the causal impact of firms' productivity on tax evasion, we employ instrumental variable (IV) strategies similar to Bai et al. (2017) who examine the effects of growth on corruption in Vietnam, and to Bachas et al. (2018) who study the effect of firm size dependent taxation on productivity across countries. The common idea in these papers is to exploit exogenous variation in industries utilizing an external benchmark.

To this end, we utilize two instruments, both of which are constructed to exploit industry-specific shocks. The first instrument is the average productivity of the same industry in other regions of the same country. The key identification assumption here is that industry-specific tax evasion is determined independently within each region, so that the instrument affects a given firm's tax evasion propensity solely through its own productivity. Our second instrument is the average productivity in the same industry in other, much larger, countries located in the same geographical region. The identifying assumption is that industry-level changes in tax evasion do not affect productivity in a country that is much larger than a country in which a given firm operates.

We find that productivity improvements by firms have statistically and economically significant effects on tax compliance of firms. Our baseline estimates suggest that an increase in productivity of 1 percent increases the sales reported to tax administrations by around 0.12 percent, indicating a response elasticity of more than ten percent. The results are unaffected by several robustness tests, including alternative measures of productivity and different controls, despite the relatively limited panel dimension.

These results reinforce and further advance the conclusions in La Porta and Shleifer (2014) and Kanbur (2017). The former study presents a strong case for cross-country correlations between productivity and the propensity to operate formally and be tax compliant. The latter study proposes a theoretical argument that productivity may affect informality. This paper's contribution in relation to this work is that it provides direct causal microeconomic evidence on this effect, specifically, in the context of tax evasion as an attribute of informality. In this regard, the paper also contributes to the literature on tax evasion-foundations for which were laid out in Allingham and Sandmo (1972) (see Andreoni, 1998, for a review). In contrast to most studies on tax evasion that focus on advanced economies, our paper examines this issue for developing economies. Whereas correlations between productivity and tax compliance have been documented, and existing work has explored the effect of the latter on the former, this paper's novelty is in conducting analysis of the causal effect productivity has on tax compliance. To our knowledge, the only paper that addresses this issue is Di Nola et al. (2017) in the context of a 
calibration of the Bulgarian economy. We, approaching the task from an empirical perspective, find similarly significant effects.

The paper is organized as follows. In Section 2, we present stylized facts using macroeconomic data. Section 3 presents a simple organizing model. In Section 4, we discuss the firm-level data and the empirical strategy. Section 5 present the results, and Section 6 concludes.

\section{Macroeconomic Stylized Facts}

In this section we present cross-country stylized facts to motivate our analysis using data from around 100 advanced and developing economies. It is commonly believed that the selfemployed exhibit lower rates of voluntary compliance than taxpayers whose primary source of income are wages and salaries, irrespective of any tax advantages that self employment may have. This disparity in reporting compliance is attributed to the lower probability of detecting unreported self-employment income. As a result, the share of self-employment is commonly used as a proxy for tax non-compliance in both developing and advanced economies (Loayza and Rigolini, 2006; Feldman and Slemrod (2007)). In Figure 1 we present a scatter plot showing the correlation between the log share of self-employment in a country and the log of GDP per capita.

The red fitted line in Figure 1 suggests that an increase of 1 percent in per capita GDP results in a decline of 0.2 percent in our measure of tax evasion (i.e., the share of self-employment). However, arguably, a simple OLS specification is potentially biased and subject to reverse causality as self-employment could also determine per capita GDP.

In order to also establish a causal relationship from GDP per capita to tax evasion, we follow Brueckner, Dabla-Norris, and Gradstein (2015) in employing two IVs. The first IV is oil price shocks (oil), defined as the interaction between the change in the international oil price and countries' average oil net-export GDP shares. This variable has been found to be a strong instrument for income changes and also extracts a very persistent component of national income. Another complementary IV is trade-weighted world income (twwi), the weighted sum of world income for each country, with time-invariant weights varying across countries depending on their trade patterns. Specifically, we estimate the following specification:

$$
\begin{array}{r}
G D P_{c t}=\alpha_{c}+\alpha_{t}+\beta_{1} t w w i_{c t}+\beta_{2} o i l_{c t}+\varepsilon_{c t} \quad-\text { first stage } \\
\text { Self-employment } \text { emt }_{c t}=\alpha_{c}+\alpha_{t}+\beta_{1} \widehat{G D P}_{c t}+\varepsilon_{c t}-\text { second stage }
\end{array}
$$

The results imply that the OLS estimate is biased downward. Importantly, a 1 percent increase in per capita GDP results in a 0.7 percent decline in tax non-compliance (measured by the share of self-employment). In Appendix 1 we include additional information on the specification and 
estimation. The slopes of the fitted values in Figure 1 correspond to specifications (1) and (2) in Table Appendix 1. 2.

Figure 1. OLS and 2-stage LS results

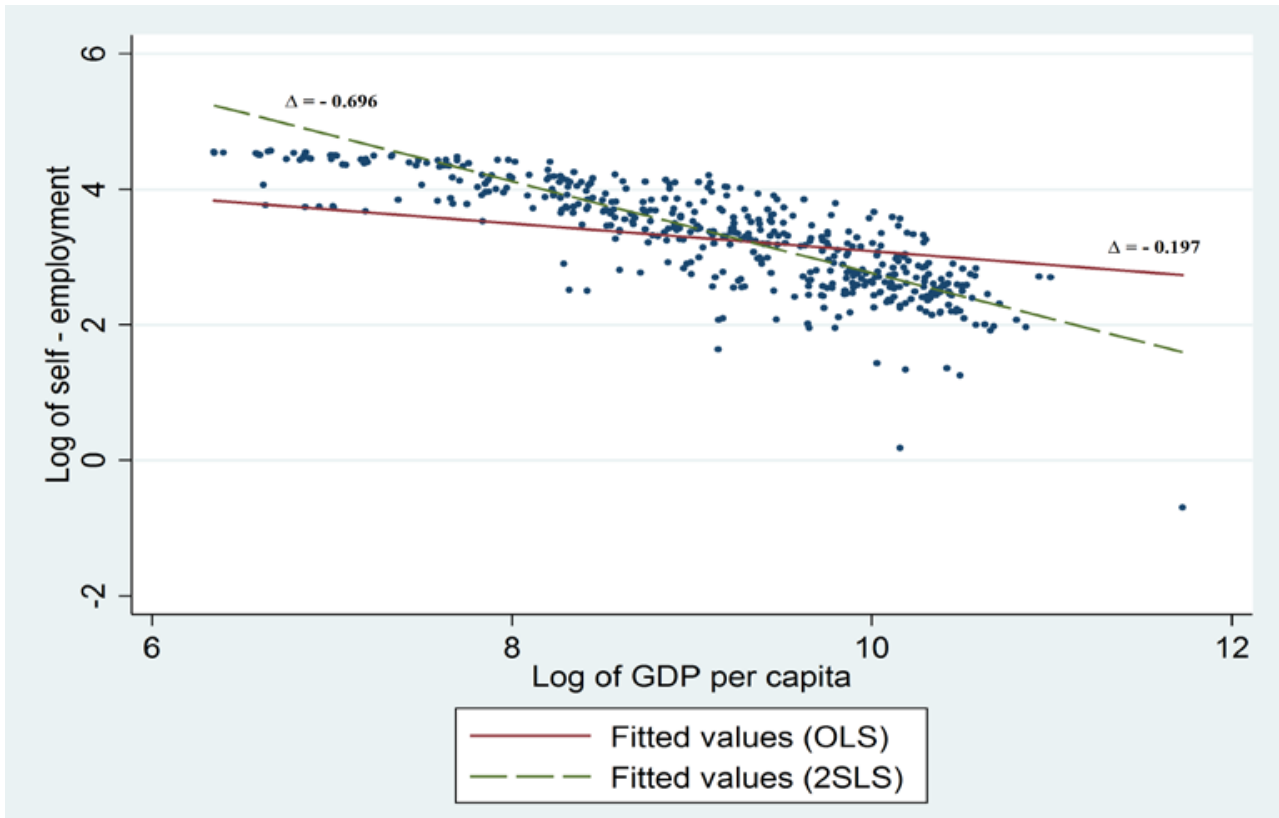

Notes: Robust standard errors, clustered at the country level. 5-year averages used. Outliers in growth, defined as $<-60 \%$ or $>60 \%$, are dropped. Outliers in self-employment, defined as countries with changes $<1$ st percentile and $>99$ th percentile, are dropped. The sample is restricted to 1980-2010. The instruments in each regression are trade-weighted world income (using trade shares from 2000-2009) and oil price shocks.

\section{ThEORETiCAL FrameWORK}

The model below is a stripped-down version of Dabla-Norris et al. (2008), which, in turn, builds upon Lucas (1978), and Rauch (1991). Such a dual economy framework has become a standard workhorse in the literature on informality and tax evasion. In particular, Dabla-Norris et al. (2008) employ it to explore the relationship between regulations and other institutional features and the extent of informality in an economy. Here we are interested in the impact of productivity on the extent of tax evasion. We ignore factor markets in the model below, which are analyzed in DablaNorris et al. (2008). This simplifies things significantly yet allows us to illustrate the main forces of interest.

We assume that there is a continuum of firms indexed $i$, operating in the context of an economy composed of two sectors, one tax compliant, and one full non-compliant (alternatively formal 
and informal). ${ }^{5}$ Output production uses technological opportunities, $A$, and managerial talent, $\alpha_{i}$ which is distributed across the firms according to the cumulative distribution function $F(a)$. The production function can be written as

$$
y_{i}=\alpha_{i} A
$$

The aggregate level of output is then the aggregate sum $Y=A \int a d F(a)$. Firms in the tax compliant sector produce according to (3) but bear the cost of complying with government taxation (at a minimum, such as simply the administrative costs associated with paying taxes) and the direct financial cost of paying taxes. Letting $C$ denote the cost of compliance and $T$ the tax rate, and normalizing the output price to one, the net profits of a firm operating in the formal sector can be written as:

$$
P_{i}^{F}=\alpha_{i} A(1-T)-C
$$

Firms that are non-compliant and operating in the other sector differ in three ways. First, they have their technological opportunities reduced, and we let $b$, where $0<b<1$, denote the reduction in these opportunities per unit. This can be the result of a limited access to the technological frontier or to other productive public goods or foregoing business opportunities. Additionally, they avoid the direct cost of regulatory requirements $C$ and cost of paying taxes $T$. Finally, they face a likelihood of being caught and fined for non-compliance with taxation, as in the pioneering work by Allingham and Sandmo (1972). We denote $p$ as the probability of being caught while non-complying with taxation and interpret it as being dependent on the quality of the legal and enforcement systems. In contrast, weak institutional quality implies lax enforcement; we suppose that, when caught, the firm is fined by the full amount of its profits.

These assumptions imply that the profits of a non-compliant firm can be written as follows:

$$
\begin{gathered}
P_{i}^{I}(\text { not caught })=a_{i} b A, \text { with probability } 1-p \\
P_{i}{ }^{I}(\text { caught })=0, \text { with probability } p
\end{gathered}
$$

so that the expected profits are

$$
E\left(P_{i}^{I}\right)=\alpha_{i} b A(1-p)
$$

The decision whether to comply or not comply with taxation is determined from:

$$
a^{*} A(1-T)-C=a^{*} b A(1-p), \text { or }
$$

\footnotetext{
${ }^{5}$ In Appendix 2, we extend the model to consider the case where firms can partially evade taxation, as suggested in Kanbur and Keen (2014). It is shown there that the qualitative nature of the results remains unchanged.
} 
$a^{*}=1 /\{A[1-T-b(1-p)]-C\}$

where $a^{*}$ denotes the cutoff productivity level. We assume that there is an interior solution, where a fraction of the firms chooses to be compliant and another fraction, denoted by $F\left(a^{*}\right)$, chooses to be non-compliant; for extreme parameters values there could be corner equilibria, which are not considered here. We then obtain the following set of implications:

(i) The cutoff productivity value, hence, the share of non-compliant firms, decreases in the productivity parameter $A$ and in quality of enforcement $p$; and it increases in the tax rate $T$ and in the administrative cost of compliance $C$.

(ii) The cutoff productivity value and the share of the firms that are not compliant increase in taxes and administrative costs less rapidly in a more productive economy; and both decrease less rapidly with the quality of enforcement in a more productive economy.

The first part of this result is obtained by differentiating equation (7). The second part follows from differentiating (7) twice. Appendix 2 provides details of the mathematical derivations.

\section{EMPIRICAL StRATEgY}

\section{A. Firm-Level Data}

To test the implications of our theoretical model at the firm level, we employ data from the World Bank Enterprise Surveys for 47 emerging and developing economies that cover manufacturing and service sectors. ${ }^{6}$ We measure tax evasion as the percentage of sales that is reported for tax purposes. The exact question in the standardized survey is: "Recognizing the difficulties many enterprises face in fully complying with taxes and regulations, what percentage of total sales would you estimate the typical establishment in your area of activity reports for tax purposes?"7

The question was included in the standardized version of the Enterprise Surveys between 2002 and 2005. For 2006 and 2010, it was included in most country-specific questionnaires, but not in the standardized one (and therefore potentially left out in some surveys) and has been dropped since 2010. This variable has been used before in empirical research to measure informality and examine its determinants (see, for example, Dabla-Norris et al., 2008), and is the only measure of the degree of tax evasion at the firm level available for many countries.

This measure is subject to three potential sources of criticism. First, it relies on self-reported information implying that it may be biased if firm managers are afraid to reveal the true (and

\footnotetext{
${ }^{6}$ As in the case of Bai et al. (2017), we do not have reliable firm identifiers that would allow us to include fixed effects without losing a very large share of our observations.

${ }^{7}$ See Appendix 3 for variable definitions and descriptive statistics.
} 
lower) share of reported income to the interviewer. As an imperfect way to address this problem, firm managers are asked to refer to firms similar to their own, based on the assumption that the respondents will still use their own behavior to answer this question. Despite these efforts, this bias can persist in variables measuring tax evasion and that are based on this type of question (Kundt et al., 2017). However, there is no obvious reason to assume that the magnitude of this bias is systematically correlated with firm-level productivity, which is our variable of interest.

Second, this is a one-dimensional measure and obviously only captures sales underreporting, but not underreporting of the wage bill for social security taxation purposes or compliance with other types of size-dependent regulations. However, as shown by Dabla-Norris and Inchauste (2008) using a firm-level data set for 27 countries in Eastern Europe and Central Asia, the correlation between self-reported sales, wage bill and employment underreporting is relatively high.

Finally, the World Bank Enterprise Surveys only capture registered firms with 5 or more employees, which implies that our analysis focuses firms that operate in the formal economy but hide at least some part of their output. We are therefore ignoring the mostly unregistered microenterprises (or "outsiders" in the Kanbur and Keen (2015) terminology) that are prevalent in any emerging and developing economies.

\section{B. Regional Instrument}

Our hypothesis is that improvements in firm productivity reduce tax evasion, measured as the percentage of sales reported for tax purposes. Testing this hypothesis directly is subject to potential endogeneity as causality could run either ways. We therefore construct two instruments, following the strategy employed in Bai et al. (2017) and Bachas et al. (2018), in related contexts.

The first strategy is to instrument for a given firm's productivity by examining the average productivity of firms operating within the same industry but located in other subnational regions of the same country. This IV strategy is based on the existence of industry-specific productivity shocks that are similar across all regions of a country, which we can test in the first stage. The key identification assumption is that industry-specific tax evasion is determined independently by each region and that there are no large-scale country-wide efforts spanning all regions to reduce tax evasion in a specific industry in a given year. If there were, the exclusion restriction would be violated because country-wide productivity shocks could be correlated with these types of unobserved crackdowns.

In contrast to Bai et al. (2017), the institutional context of strategies to combat tax evasion is not observed for every year and country. However, international best practice suggests that tax administrations should segment taxpayers primarily by size to tailor enforcement actions (IMF, 2015a). In addition, given that resources of tax administrations are often limited, it seems 
plausible that they do not spread them thinly across all taxpayers within a relatively broad industry, but rather employ risk-based auditing approaches.

To construct this instrument, we use information on the subnational region or city. If that information is not available, we make use of information on the size and type of the city that often allows us distinguishing between two cities or regions (see Appendix 4 for details). For instance, in Ecuador this variable indicates if the city where the firm is located has more than one million inhabitants and whether the firm is located in the capital. For some surveys, information on the location of the firms within countries is not available, or all firms are essentially located within the same region or city (which is especially the case of small countries). For consistency purposes, we only distinguish two regions for all countries even if the data allow for identifying several regions, namely the biggest one and another one which includes all other locations that we can identify. This approach avoids creating too many regions with a small number of observations and ensures that countries are not divided into more than two regions simply because of higher data quality.

Cross-regional variation in the average percentage of sales reported appears to be large, ranging from around 8 to 100 percent with a standard deviation of 19 percent (using the full sample of firms, the standard deviation is 28 percent and, therefore, not much higher). In addition, the within-country-across region variation also seems sizeable. The differences between the average sales reported in both regions of each country averages around 7 percent. This implies that, on average, firms in the region with higher tax compliance report 7 percent more of their sales to the tax authorities compared to the region with lower average tax compliance in a given country.

\section{International Instrument}

The second instrument employed is the average productivity in the same industry in larger neighboring countries than the country where the firm is located. As in Bai et al. (2017), the idea is that many industries in countries within the same geographical region are subject to the same productivity shocks, similarly to the case of the regional IV. However, because the country that is used as an instrument is so much larger, reverse causation, whereby changes in informality of a particular industry and country would substantially affect productivity in the same industry of the much larger country used as an instrument, is unlikely. Further, constructing an instrument using data from countries that are much larger and located nearby appears a plausible strategy to ensure that observed changes in productivity are relevant for firms located in smaller countries.

Bai et al. (2017) use data from China as an instrument for Vietnam, which may be an obvious country pair for this type of IV strategy. However, for other countries and regions, such obvious 'candidates' are not easy to identify or are not easily available, as we do not have firm-level data from all countries and years. In addition, there may be several countries which seem suitable to construct the instrument. 
We therefore proceed as follows. First, we group all countries into geographical regions as defined by the World Bank (WB). The WB regions we consider include Europe and Central Asia, Latin America and Caribbean, Middle East and North Africa, South, East Asia and Pacific, and Sub-Saharan Africa. We only slightly deviate from the World Bank classification and reclassify Turkey to be part of Middle East and North Africa (see Appendix 4 for details).

Second, for every year and every WB region, we construct the IV using the data from the two largest economies which we omit from our sample. For each of the remaining countries within each WB region and year, we check if their GDP in PPP terms at least five times smaller than that of each of the two largest economies. If the GDP is only five time smaller than that of the largest economy, we only construct the instrument using data from the largest economy for that particular country. If the GDP is not at least five times smaller than that of the largest economy, we omit the country from our sample. If the second biggest country in each year and WB region is not five times bigger than any of the remaining countries, we still remove it from the sample for consistency purposes.

Third, we only match firms that are both commodity exporters or both classified as not being commodity exporters. We define commodity exporters as countries that export oil, gas, and metals (such as copper, gold, iron, and silver), where these commodities represent a large share of exports (20 percent or more of total exports) or fiscal revenues (IMF, 2015b). In other words, we construct instruments for commodity exporters within each WB region and year and for noncommodity exporters within each WB region and year. This ensures that the countries used as instruments share sufficient structural similarities with the countries where firm productivity is instrumented (we relax this assumption as a robustness check). In the Appendix Table 4.2 we list all country pairs. Finally, to construct the IV, we first compute average productivity within each industry in the countries that are used as instruments, and then take logs. We use the average across countries if two countries are used as instruments.

The first stage suggests that average productivity at the industry level is correlated between the countries that are used as an instrument and those that are not (see Tables in Appendix 5), suggesting that industry-specific shocks are similar across the countries we pair. Nevertheless, some paired countries could plausibly share fewer similarities than Vietnam and China, not least because they have different levels of development or because they are located much further apart and may have differently structured economies. We, therefore, set a relatively high size threshold to address this possibility. Specifically, we assume that productivity shocks in major regional economies feed through to smaller economies in the same region and test the robustness of the way this instrument is constructed in several ways. 


\section{ECONOMETRIC RESULTS}

\section{A. OLS}

We begin by running simple OLS regressions:

$$
\text { Sales_Reported }_{i j r c t}=\alpha_{r j}+\alpha_{r t}+\beta_{1} \text { Prod }_{i j r c t}+\beta_{2} \text { Controls }_{i j r c t}+\varepsilon_{i j r c t}
$$

where Sales_Reported refers to the percent of sales reported for tax purposes as reported by firm $i$ operating in industry $j$, located in region $r$ of country $c$ in year $t$. Prod refers to the log of productivity of the same firm defines as sales per worker, and Controls represent control variables. The latter include the age of the firm (in logs, to account for non-linear effects), whether the firm exports, whether it is foreign-owned, whether it is government-owned and subjective rating of tax administration in relative terms. The exact definitions of these variables are included in Table Appendix 3. 1. We implement two-way clustering at the (within-country) region and industry-year level to correct for possibly correlated errors across time and industry and include region-industry effects $\left(\alpha_{r j}\right)$ as well as region-year fixed effects $\left(\alpha_{r t}\right)$ to control for unobserved time-variant and region-specific factors, such as subnational changes in the tax code for example.

One important limitation of our data is the limited panel dimension. We observe, on average, each region 13 and each region-industry combination 16 times, which matters as we include region-industry fixed effects in our regressions. To maximize sample size and potentially avoid a further reduction in sample size, we use labor productivity, defined as sales over employment, as our firm-level productivity indicator. ${ }^{8}$ However, we show that the results are similar when using value-added per worker or TFP estimated using the Levinsohn and Petrin (2003) estimator. As mentioned above, we control for subjective perceptions of the severity of tax administration as a business constraint which could likewise affect the propensity to evade taxation. To control for firm-level differences in this variable, we follow the literature and divide the rating of this constraint by the average subjective rating of all constraints that could plausibly affect tax compliance (Misch et al, 2014). Apart from tax administration, these include tax rates, access to finance and competition from informal companies.

Table 1 presents the baseline results. In specification (1) we measure productivity using sales per employee (in logs). The coefficient on the labor productivity variable is significant but relatively small in magnitude, suggesting that a 1 percent increase in firm productivity results in 0.01 percentage points increase in the share of sales reported for tax purposes. In specification (2) we restrict the sample to the sample of our IV baseline presented in Table 2 for comparison purposes; but the coefficient of interest does not change significantly.

\footnotetext{
${ }^{8}$ Strictly speaking, we only observe revenue (and not physical) productivity which could be subject to firm-specific markups.
} 
Table 1. OLS Results

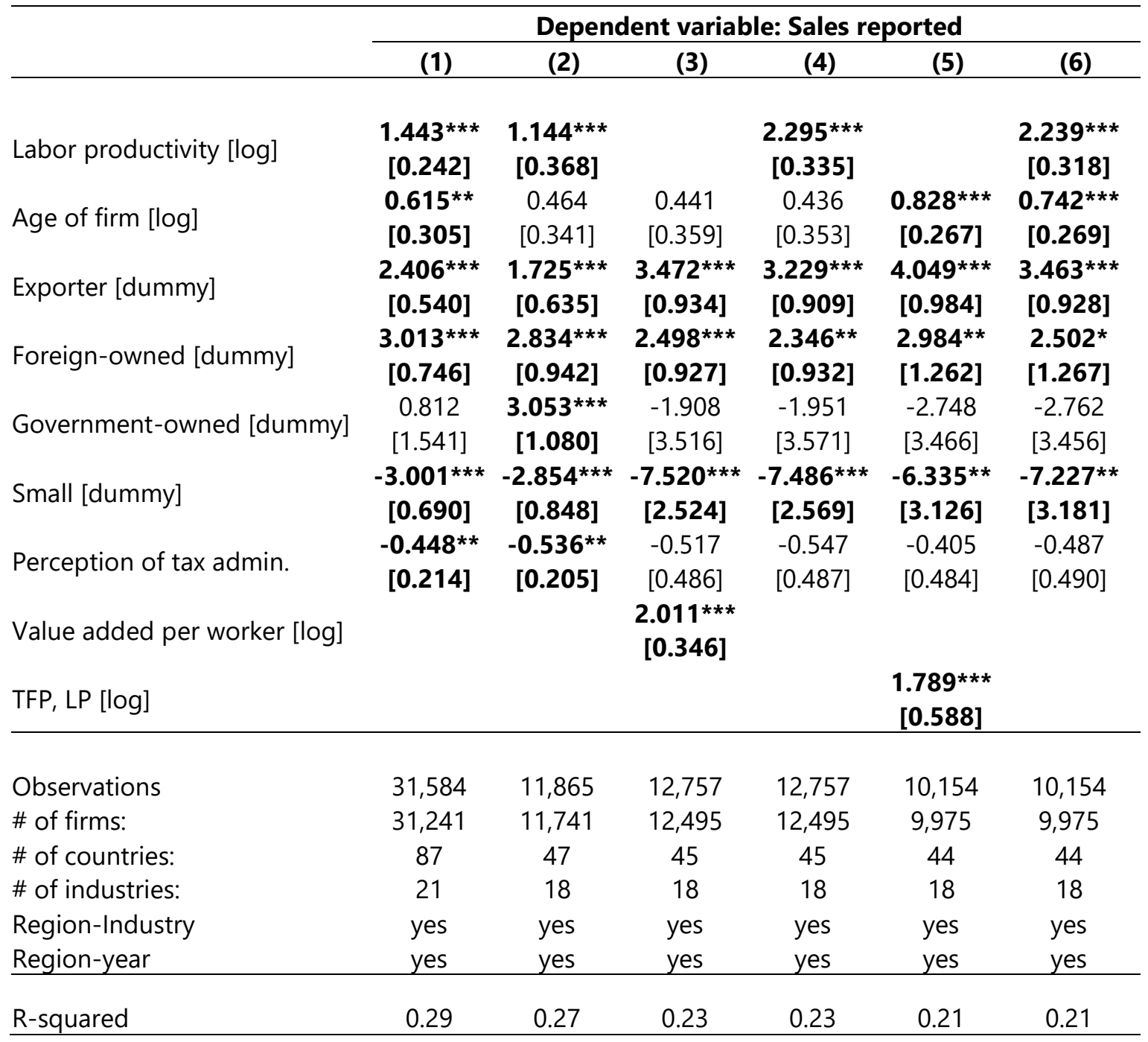

${ }^{\star * \star *} p<0.01,{ }^{* \star} p<0.05,{ }^{*} p<0.1$

Notes: Errors in brackets clustered at the region and industry-year level.

Spec. 1 is a baseline OLS regression on the entire sample with revenue-based productivity.

Spec. 2 is an OLS regression on the IV sample with revenue-based productivity.

Spec. 3 is an OLS regression on the entire sample with value-added-based productivity.

Spec. 4 is an OLS regression on the value-added sample with revenue-based productivity.

Spec. 5 is an OLS regression on the entire sample with TFP.

Spec. 6 is an OLS regression on the TFP sample with revenue-based productivity.

Given that sales per employee is an imperfect measure of productivity, in the remaining specifications of Table 1, we examine whether using alternative measures of productivity (which shrink the sample significantly) yields qualitatively similar results. In specification (3), we use value added per worker (in logs) as a measure of productivity. In specification (5), we use a measure of firm-level TFP, based on the Levisohn and Petrin (2003) production function approach. In specification (4) and (6), we use the same samples as in specifications (3) and (5), respectively, but use labor productivity instead as in the baseline. The coefficients are similar in magnitude when 
the same country sample is used, suggesting that labor productivity is a suitable indicator for productivity in our setting.

\section{B. IV Regressions}

Given that the coefficient on the productivity indicator is likely to be biased due to potential reverse causality, we use the average productivity of firms operating in the same industry but located in other regions of the same country, and of firms operating in other, much larger countries in the same geographical WB region where the firm is located, as instruments. We use both instruments at the same time to be able to test for instrument validity using the Hansen J test. Relative to a simple OLS specification, the sample shrinks significantly as we are only able to use the overlap between those firms for which the regional and the international instrument is available. We estimate the following first-stage regression where the standard errors are again clustered at the subnational region and industry-year level:

$$
\operatorname{Prod}_{i j r t}=\alpha_{r j}+\alpha_{r t}+\beta_{1} \operatorname{Prod}_{j-r c t}+\beta_{2} \operatorname{Prod}_{j r x t}+\beta_{3} \text { Controls }_{i j r t}+\varepsilon_{i j r c}
$$

Where $\operatorname{Prod}_{j-r c t}$ is log of average productivity of firms operating in the same industry but located in the other region of the same country, Prod $_{j r x t}$ is the log of average productivity of firms operating in the same industry but located in countries that are chosen as an instrument and where Controls $s_{i j t}$ represent firm-level control variables as above. The second stage is analogous to the previous subsection:

$$
\text { Sales_Reported }_{i j r c t}=\alpha_{r j}+\alpha_{r t}+\beta_{1} \widehat{\text { Prod }}_{j r c t}+\beta_{2} \text { Controls }_{i j r c t}+\varepsilon_{i j r c t}
$$

Table Appendix 3. 2 contains descriptive statistics of the sample used in our IV baseline estimation.

Table 2 presents the results. Specification (1) is our baseline regression. The coefficient on labor productivity (in logs) is significant and much larger compared to specification (2) in Table 1 which is based on the same sample, implying that the OLS estimates are biased downward being subject to classical measurement error. The resulting attenuation bias more than compensates the potential reverse causality effect. Our IV estimates suggest that increasing labor productivity by 1 percent increases the share of sales reported for tax purposes by 0.12 percentage points, a result which is also economically significant.

The sign of the coefficients on the control variables appear plausible (except for the age variable which changes sign across specifications and is never significant). Government-owned firms report a higher share of sales. Small firms and firms that view tax administration as a greater constraint report a lower share of sales for tax purposes. The coefficients on the foreign-owned firms and exporter dummies are negative suggesting that they report a lower share of sales for tax purposes, but the estimates are mostly not statistically significant. However, the negative sign 
could be explained by the way the survey question to construct the dependent variable is framed as respondents are asked to estimate tax evasion in firms similar to their own.

Table 2. IV Results

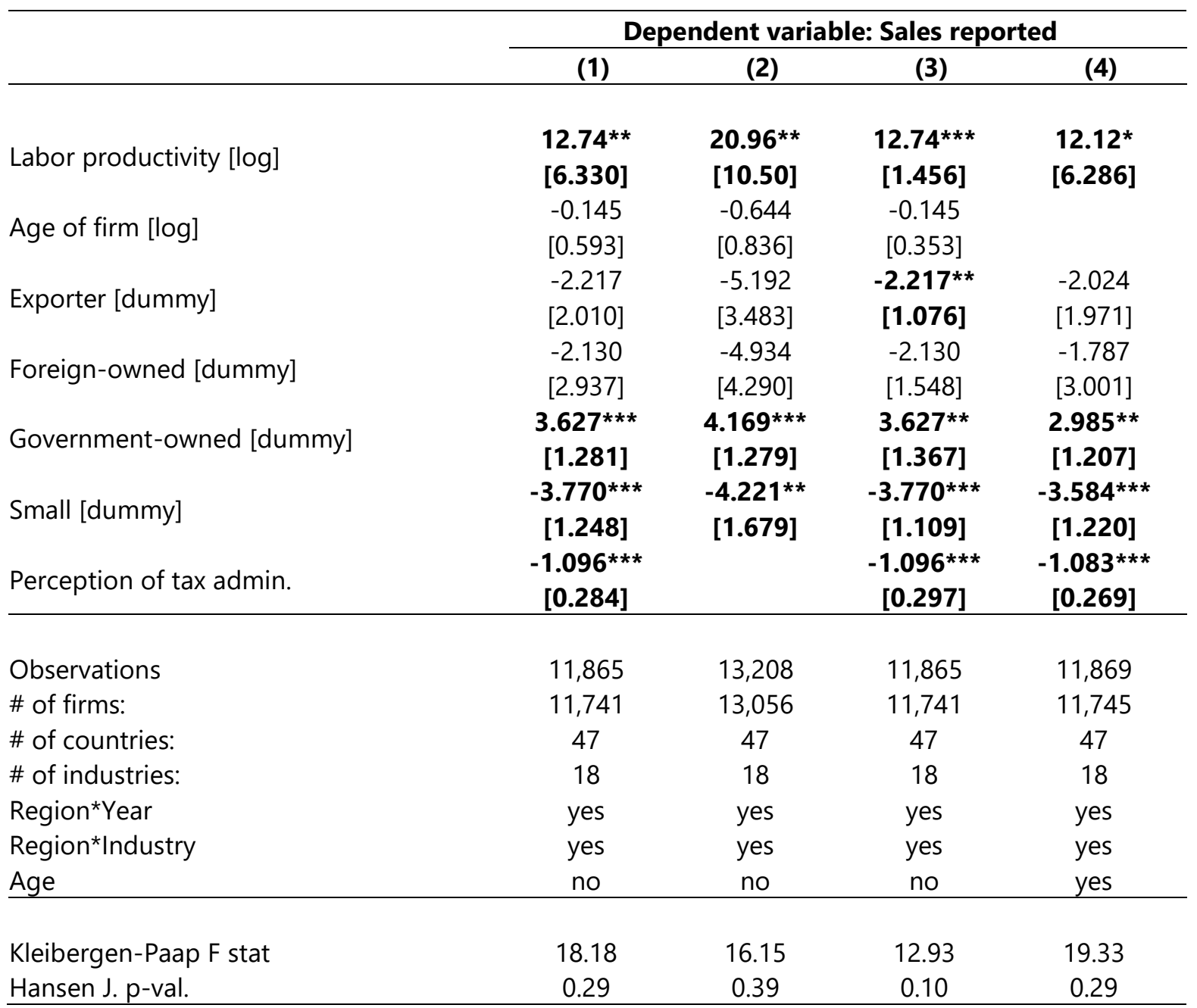

${ }^{* * *} p<0.01,{ }^{* *} p<0.05,{ }^{*} p<0.1$

Notes: Errors in brackets clustered at the region and industry-year level except in spec. 3 where clustering is at the country-year level.

IV-1 is the simple average of productivity in other regions of the same country, industry and year.

IV-2 is average productivity in the same industry and year in two other countries in the sample that have a GDP that is at least 5 times as large and are located in the same World Bank region. In addition, we do not match commodity exporters with non-commodity exporters. 
In the remaining specifications in Table 2, we test the robustness of our main result in several ways and show that the coefficients remain significant and of similar magnitude. In specification (2) we remove the control for subjective perception of tax administration which leads to an increase in the sample size by almost 10 percent. In specification (3), we cluster at the countryyear level instead at the region and industry-year level. In specification (4) we remove Age as a control variable and add age fixed effects instead. The coefficient of labor productivity is significant throughout and of broadly similar magnitude, except in specification (2), where it is larger.

To test the quality of our instrumental variable regressions, we report the first-stage KleibergenPaap F-statistic, a measure of the instruments' relevance. This test statistic is well in excess of 10 in all regressions. Thus, we can reject weak instrument bias according to the criterion provided in Staiger and Stock (1997). In addition, the p-value of the Hansen J test is always 0.1 or higher, suggesting that we cannot reject the hypothesis that the instruments are valid. Finally, the first stage coefficients on both instruments are significant throughout, and their sum is below one which is plausible (see Table Appendix 5. 1).

\section{Robustness Checks}

To ensure the robustness of the estimated impact of labor productivity on the percentage of sales reported for tax purposes, we conduct several robustness checks. Table 3 presents the results. In specification (1) we relax the size difference between countries that are paired and only require that the countries used as instruments are four times as large as the countries where the firms whose productivity is instrumented are located. This increases the sample size and allows us to test the robustness of the precise specification of the size threshold that we use in the baseline specification. In specification (2) we exclude all advanced economies from our sample as the dynamics of productivity and tax evasion could fundamentally differ in these countries. In specification (3) we match countries irrespective of whether they are both commodity exporters or not to increase the sample size. In specification (4) we construct regional IV only if there are at least 5 firms in the other region (in the baseline we do not impose any such restriction). All estimated coefficients are comparable in size with those of the baseline IV.

\section{CONCLUSION}

Improving tax compliance has long been a core development objective, both to enhance revenue and as essential to building strong, trusted public institutions. In this paper, we show that improvements in productivity lower tax evasion. This proposition has been made in the literature on theoretical grounds, but so far has not been tested rigorously in a way that addresses endogeneity concerns. To motivate our analysis, we present stylized facts using macroeconomic data, suggesting that the level of per capita GDP causally affects tax evastion. We then develop a model where firms decide whether to be tax compliant based on their exogenously given productivity. Finally, using an IV strategy, we show that firm-level productivity causally affects the level of tax evasion. 
Our findings have interesting policy implications which complement the usual policy prescriptions to combat tax evasion (IMF, 2015a). They suggest that broader efforts to improve productivity can yield tax compliance gains, increasing tax revenue collection. Such efforts could complement reforms to tax policy and tax administration aimed at reducing tax evasion.

There are some caveats to other analysis. Our IV strategy relies on changes in industry-level productivity, which could also be driven by firm entry and exit and changes in reallocation, rather than by shocks that directly affect firm-level productivity. However, given the limited time span, it seems unlikely that changes in industry-level productivity are mainly the result of say changes in within-industry changes of the allocation of resources. Future research could examine narrative evidence that supports the assumption that there are industry-level changes in tax enforcement and additionally analyze the mechanisms through which productivity affects tax compliance. 
Table 3. IV Robustness Checks

\begin{tabular}{|c|c|c|c|c|}
\hline & Dep & ndent varia & e: Sales rep & ted \\
\hline & (1) & (2) & (3) & (4) \\
\hline & $17.70 *$ & $12.74 * *$ & $12.64^{*}$ & $12.42 *$ \\
\hline Labor productivity [log] & {$[10.00]$} & [6.377] & [6.530] & [7.211] \\
\hline & 0.349 & -0.255 & -0.620 & -0.137 \\
\hline Age of firm [log] & {$[0.935]$} & [0.629] & {$[0.735]$} & [0.646] \\
\hline & -5.160 & -2.568 & -1.937 & -2.164 \\
\hline Exporter [aummy] & [3.978] & [2.154] & [2.234] & [2.376] \\
\hline & -4.448 & -2.823 & -3.845 & -2.538 \\
\hline roreign-ownea [aummy] & [4.527] & [3.338] & [3.836] & [3.531] \\
\hline & -10.92 & $2.745 * *$ & 3.527 & $3.560 * *$ \\
\hline Government-ownea [aummy] & [12.50] & [1.290] & [3.016] & [1.547] \\
\hline & $-4.426 * * *$ & $-5.096 * * *$ & $-7.160 * * *$ & $-3.374 * * *$ \\
\hline small [dummy] & [1.634] & [1.668] & [2.415] & [1.158] \\
\hline & 0.506 & $-1.139 * * *$ & $-1.281 * * *$ & $-1.046 * * *$ \\
\hline Perception of tax admın. & {$[1.573]$} & {$[0.294]$} & {$[0.470]$} & {$[0.327]$} \\
\hline Observations & 13,618 & 9,980 & 13,937 & 10,198 \\
\hline \# of firms: & 13,464 & 9,856 & 13,725 & 10,079 \\
\hline \# of countries: & 50 & 38 & 54 & 46 \\
\hline \# of industries: & 18 & 18 & 20 & 17 \\
\hline Region*Year & yes & yes & yes & yes \\
\hline Region*Industry & yes & yes & yes & yes \\
\hline Kleibergen-Paap F stat & 17.39 & 17.65 & 16.90 & 19.20 \\
\hline Hansen J. p-val. & 0.86 & 0.29 & 0.30 & 0.33 \\
\hline $\begin{array}{l}{ }^{* *} p<0.01,{ }^{* *} p<0.05,{ }^{*} p<0.1 \\
\text { Notes: Errors in brackets clustered at } \\
\text { other regions of the same country, i } \\
\text { in up to two other countries in the } s \\
\text { same World Bank geographic regior } \\
\text { exporters. Spec. } 1 \text { uses average proc } \\
\text { excludes advanced economies. Spec } \\
\text { irrespective of whether they are com } \\
\text { firms in the other region. }\end{array}$ & $\begin{array}{l}\text { ind industry-y€ } \\
\text { /ear. IV-2 is ave } \\
\text { ave a GDP that } \\
\text { we do not ma } \\
\text { untries that ar } \\
\text { tries for the } c \\
\text { rters or not. } S \text { I }\end{array}$ & $\begin{array}{l}\text { level. IV-1 is } \\
\text { age productivi } \\
\text { at least } 5 \text { tim } \\
\text { h commodity } \\
\text { at least } 4 \text { time } \\
\text { struction of th } \\
\text { c. } 4 \text { constructs }\end{array}$ & $\begin{array}{l}\text { erage producti } \\
\text { in the same in } \\
\text { as large and a } \\
\text { porters with nc } \\
\text { as large for IV- } \\
\text { international ir } \\
/-1 \text { only if ther }\end{array}$ & $\begin{array}{l}\text { y of firms in } \\
\text { istry and year } \\
\text { located in the } \\
\text {-commodity } \\
\text { Spec. } 2 \\
\text { rument } \\
\text { are at least } 5\end{array}$ \\
\hline
\end{tabular}




\section{References}

Allingham, Michael G., and Agnar Sandmo. "Income tax evasion: A theoretical analysis." Journal of Public Economics 1, no 3-4 (1972): 323-338.

Alm, James, Jorge Martinez-Vazquez, and Chandler McClellan. "Corruption and firm tax evasion." Journal of Economic Behavior \& Organization 124 (2016): 146-163.

Almeida, Rita, and Pedro Carneiro. "Enforcement of labor regulation and firm size." Journal of Comparative Economics 37, no. 1 (2009): 28-46.

Amin, Mohammad, Franziska L. Ohnsorge, and Cedric Okou, "Casting a Shadow. Productivity of Formal Firms and Informality." (2019) World Bank Policy Research Working Paper 8945.

Andreoni, James, Brian Erard, and Jonathan Feinstein. "Tax compliance." Journal of Economic Literature 36, no. 2 (1998): 818-860.

Bachas, P., R.N. Fattal Jaef, and A. Jensen. "Size-Dependent Tax Enforcement and Compliance: Global Evidence and Aggregate Implications," Policy research WP 8363, World Bank (2018).

Bai, Jie, Seema Jayachandran, Edmund J. Malesky, and Benjamin A. Olken. "Firm growth and corruption: Empirical evidence from Vietnam." The Economic Journal (2017).

Benjamin, Nancy C., and Ahmadou Aly Mbaye. "The informal sector, productivity, and enforcement in West Africa: A firm-level analysis." Review of Development Economics 16, no. 4 (2012): 664-680.

Bobbio, Emmanuele. "Tax evasion, firm dynamics and growth." Questioni di Economia e Finanza (Occasional Papers) 357, Bank of Italy, Economic Research and International Relations Area (2016).

Brueckner, Markus, Era Dabla Norris, and Mark Gradstein. "National income and its distribution." Journal of Economic Growth 20, no. 2 (2015): 149-175.

Busso, Matías, Maria Fazio, and Santiago Algazi. "(In) formal and (un) productive: The productivity costs of excessive informality in Mexico." (2012).

Dabla-Norris, Era, and Andrew Feltenstein. "An analysis of the underground economy and its macroeconomic consequences." IMF working paper 3-23 (2003).

Dabla-Norris, Era, Mark Gradstein, and Gabriela Inchauste. "What causes firms to hide output? The determinants of informality." Journal of Development Economics 85, no. 1-2 (2008): 127. 
Dabla-Norris, Era, and Gabriela Inchauste. "Informality and regulations: What drives the growth of firms?" IMF Staff Papers 55, no. 1 (2008): 50-82.

Di Nola, A., G. Kocharkov, and A. Vasilev. "Productivity, Taxation and Evasion: An Analysis of the Determinants of the Informal Economy," Working Paper Series of the Department of Economics, University of Konstanz 2017-04 (2017).

Fajnzylber, Pablo, William F. Maloney, and Gabriel V. Montes-Rojas. "Does formality improve micro-firm performance? Evidence from the Brazilian SIMPLES program." Journal of Development Economics 94, no. 2 (2011): 262-276.

Feldman, Naomi E., and Joel Slemrod. "Estimating tax noncompliance with evidence from unaudited tax returns." The Economic Journal 117, no. 518 (2007): 327-352.

Friedman, Eric, Simon Johnson, Daniel Kaufmann, and Pablo Zoido-Lobaton. "Dodging the grabbing hand: the determinants of unofficial activity in 69 countries." Journal of Public Economics 76, no. 3 (2000): 459-493.

Friesenbichler, Klaus S., Eva Selenko, and George Clarke. "Perceptions of corruption: An empirical study controlling for survey bias." Journal of Interdisciplinary Economics 30, no. 1 (2018): 55-77.

Gelb, Alan, Taye Mengistae, Vijaya Ramachandran, and Manju Kedia Shah. "To formalize or not to formalize? Comparisons of microenterprise data from southern and east Africa." (2009).

Gordon, Roger, and Wei Li. "Tax structures in developing countries: Many puzzles and a possible explanation." Journal of Public Economics 93, no. 7-8 (2009): 855-866.

IMF 2015(a). Staff Report: "Current challenges in revenue mobilization: Improving tax compliance." (April, 2015).

IMF 2015(b). Fiscal Monitor: "The commodities roller coaster. A fiscal framework for uncertain times." (October 2015).

Jensen, Anders. "Employment structure and the rise of the modern tax system." Job market paper (2016).

Joshi, Anuradha, Wilson Prichard, and Christopher Heady. "Taxing the informal economy: The current state of knowledge and agendas for future research." The Journal of Development Studies 50, no. 10 (2014): 1325-1347.

Kanbur, Ravi, and Michael Keen. "Thresholds, informality, and partitions of compliance." International Tax and Public Finance 21, no. 4 (2014): 536-559. 
Kanbur, Ravi, and Michael Keen. "Rethinking Informality. "available at https://voxeu.org/article/rethinking-informality (2015).

Kanbur, Ravi. "Informality: Causes, consequences and policy responses." Review of Development Economics 21, no. 4 (2017): 939-961.

Kleven, Henrik Jacobsen, Martin B. Knudsen, Claus Thustrup Kreiner, Søren Pedersen, and Emmanuel Saez. "Unwilling or unable to cheat? Evidence from a tax audit experiment in Denmark." Econometrica 79, no. 3 (2011): 651-692.

Kleven, Henrik J., Claus T. Kreiner, and Emmanuel Saez. "Why can modern governments tax so much? An agency model of firms as fiscal intermediaries." Economica 83, no. 330 (2016): 219-246.

Kundt, Thorben, Florian Misch, and Birger Nerré. "Re-assessing the merits of measuring tax evasions through surveys: Evidence from Serbian firms." (2017).

La Porta, Rafael, and Andrei Shleifer. "Informality and development." Journal of Economic Perspectives 23(3), 109-126, (2014).

Levinsohn, James, and Amil Petrin. "Estimating production functions using inputs to control for unobservables." The Review of Economic Studies 70, no. 2 (2003): 317-341.

Levy, Santiago. "Under-rewarded efforts. The elusive quest for prosperity in Mexico." InterAmerican Development Bank, 2018. Available at: https://webimages.iadb.org/publications/english/document/Under-Rewarded-Efforts-TheElusive-Quest-for-Prosperity-in-Mexico.pdf

Lewis, W. Arthur. "Economic development with unlimited supplies of labour." The Manchester School 22, no. 2 (1954): 139-191.

Loayza, Norman V. "The economics of the informal sector: A simple model and some empirical evidence from Latin America." Policy Research Working Paper 1727, World Bank (1999).

Loayza, Norman V., and Jamele Rigolini. Informality trends and cycles. The World Bank (2006).

Lucas Jr, Robert E. "On the size distribution of business firms." The Bell Journal of Economics, 9(2) (1978): 508-523.

Misch, Florian, Norman Gemmell, and Richard Kneller. "Using surveys of business perceptions as a guide to growth-enhancing fiscal reforms." Economics of Transition 22, no. 4 (2014): 683-725.

Rauch, James E. "Modelling the informal sector formally." Journal of Development Economics 35(1) (1991): 33-47 
Sarte, Pierre-Daniel G. "Informality and rent-seeking bureaucracies in a model of long-run growth." Journal of Monetary Economics 46(1) (2000): 173-197.

Slemrod, Joel. "A general model of the behavioral response to taxation." International Tax and Public Finance 8, no. 2 (2001): 119-128.

Slemrod, Joel, and Caroline Weber. "Evidence of the invisible: toward a credibility revolution in the empirical analysis of tax evasion and the informal economy." International Tax and Public Finance 19, no. 1 (2012): 25-53. Staiger, Douglas, and James H. Stock.

"Instrumental variables regression with weak instruments." Econometrica 65, no. 3 (1997): pp. 557-586. 


\section{Appendix 1. Macroeconomic Stylized Facts: Details of the Estimation and Robustness Checks}

\section{Table Appendix 1. 1. Variable Definitions}

\begin{tabular}{|c|c|c|}
\hline \multicolumn{3}{|c|}{ Macro variables } \\
\hline GDP & Real GDP per capita (WEO) & $\log$ \\
\hline Self-employment & $\begin{array}{l}\text { Self-employed, total (\% of total employed) (Key Indicators of } \\
\text { the Labour Market 2015, ILO) }\end{array}$ & $\log$ \\
\hline oil & $\begin{array}{l}\text { The interaction between the change in the international oil } \\
\text { price and countries' average oil net-export GDP shares }\end{array}$ & number \\
\hline twwi & $\begin{array}{l}\text { The weighted sum of world income for each country with } \\
\text { time-invariant weights varying across countries depending on } \\
\text { their trade patterns }\end{array}$ & number \\
\hline LIC & 1 for low income countries, 0 otherwise & binary \\
\hline APD & 1 for countries in the Asia-Pacific region, 0 otherwise & binary \\
\hline EUR & 1 for countries in the European region, 0 otherwise & binary \\
\hline WHD & 1 for countries in the Western Hemisphere, 0 otherwise & binary \\
\hline post-95 & 1 for observations after 1995,0 otherwise & binary \\
\hline Rural population & Rural population expressed in percent of total population (WB) & percent \\
\hline Tax revenue & Tax revenue expressed in percent of GDP (WEO) & percent \\
\hline Rule of law & $\begin{array}{l}\text { Degree of a legal system strength from } 0 \text { [min] to } 6 \text { [max] } \\
\text { (World Government Indicators, WB) }\end{array}$ & number \\
\hline Schooling & $\begin{array}{l}\text { Average number of years a person }(15+) \text { attended a school or } \\
\text { received any formal education (Barro, 2013) }\end{array}$ & number \\
\hline
\end{tabular}


Table Appendix 1. 2. Baseline specifications

\begin{tabular}{|c|c|c|c|c|c|c|c|}
\hline & \multicolumn{7}{|c|}{ Dependent variable: Self-employment } \\
\hline & $\begin{array}{c}\text { (1) } \\
\text { OLS }\end{array}$ & $\begin{array}{c}(2) \\
2 S L S, \\
\text { baseline } \\
\text { sample }\end{array}$ & $\begin{array}{c}\text { (3) } \\
2 S L S, \\
\text { baseline } \\
\text { sample }\end{array}$ & $\begin{array}{c}\text { (4) } \\
\text { 2SLS, } \\
\text { baseline } \\
\text { sample }\end{array}$ & $\begin{array}{c}\text { (5) } \\
\text { 2SLS, } \\
\text { baseline } \\
\text { sample }\end{array}$ & $\begin{array}{c}\text { (6) } \\
2 \text { SLS, } \\
\text { baseline } \\
\text { sample }\end{array}$ & $\begin{array}{c}\text { (7) } \\
\text { 2SLS, all-control } \\
\text { variables sample } \\
1 /\end{array}$ \\
\hline GDP & $\begin{array}{c}-0.197^{* *} \\
{[0.085]}\end{array}$ & $\begin{array}{c}-0.696 * * * \\
{[0.227]}\end{array}$ & $\begin{array}{c}-0.698 * * * \\
{[0.227]}\end{array}$ & $\begin{array}{c}-0.760 * * * \\
{[0.217]}\end{array}$ & $\begin{array}{c}-0.610 * * * \\
{[0.186]}\end{array}$ & $\begin{array}{c}-0.724^{* * *} \\
{[0.190]}\end{array}$ & $\begin{array}{c}-0.483^{* * *} \\
{[0.134]}\end{array}$ \\
\hline Rural population & & & $\begin{array}{c}0.001 \\
{[0.005]}\end{array}$ & & & $\begin{array}{c}0.002 \\
{[0.006]}\end{array}$ & $\begin{array}{c}0.000 \\
{[0.005]}\end{array}$ \\
\hline Tax revenue & & & & $\begin{array}{c}0.007 \\
{[0.007]}\end{array}$ & & $\begin{array}{c}0.010 \\
{[0.006]}\end{array}$ & $\begin{array}{c}0.005 \\
{[0.005]}\end{array}$ \\
\hline Rule of law & & & & & $\begin{array}{c}0.050 \\
{[0.072]}\end{array}$ & $\begin{array}{c}0.113 \\
{[0.078]}\end{array}$ & $\begin{array}{c}0.055 \\
{[0.062]}\end{array}$ \\
\hline Schooling & & & & & & & $\begin{array}{l}-0.009 \\
{[0.023]}\end{array}$ \\
\hline Observations & 461 & 461 & 461 & 290 & 349 & 271 & 252 \\
\hline \# of countries & 101 & 101 & 101 & 86 & 101 & 86 & 78 \\
\hline Country & yes & yes & yes & yes & yes & yes & yes \\
\hline Year & yes & yes & yes & yes & yes & yes & yes \\
\hline F stat & 6.474 & 6.387 & 5.575 & 5.839 & 6.932 & 4.527 & 5.282 \\
\hline Kleibergen-Paap F stat & & 13.45 & 13.65 & 27.98 & 57.15 & 43.28 & 21.71 \\
\hline Hansen J stat p-value & & 0.242 & 0.231 & 0.179 & 0.226 & 0.280 & 0.201 \\
\hline
\end{tabular}

${ }^{* * *} p<0.01,{ }^{* *} p<0.05,{ }^{*} p<0.1$

Notes: Robust standard errors, clustered at the country level, are in brackets. 5-year averages used. Log of self-employment is the $Y$ variable for each regression. Outliers in growth, defined as $<-60 \%$ or $>60 \%$, are dropped. Outliers in self-employment, defined as countries with changes < 1st percentile and > 99th percentile, are dropped. The instruments in each regression are trade-weighted world income (using average trade shares from 2000-2009) and oil price shocks. 
Table Appendix 1. 3. Robustness checks

\begin{tabular}{|c|c|c|c|c|}
\hline & \multicolumn{4}{|c|}{ Dependent variable: Self-employment } \\
\hline & $\begin{array}{c}\text { (1) } \\
\text { Major oil- } \\
\text { exporters } \\
\text { excluded }\end{array}$ & $\begin{array}{c}\text { (2) } \\
\text { Open } \\
\text { economies } \\
\text { excluded }\end{array}$ & $\begin{array}{c}\text { (3) } \\
\text { LICs } \\
\text { excluded }\end{array}$ & $\begin{array}{c}(4) \\
\text { 10-year } \\
\text { average } \\
\text { data, } \\
\text { baseline } \\
\end{array}$ \\
\hline GDP & $\begin{array}{c}-0.664^{* * *} \\
{[0.239]}\end{array}$ & $\begin{array}{c}-0.642 * * * \\
{[0.211]}\end{array}$ & $\begin{array}{c}-0.715^{* * *} \\
{[0.261]}\end{array}$ & $\begin{array}{c}-0.648 * * * \\
{[0.174]}\end{array}$ \\
\hline Observations & 440 & 401 & 437 & 295 \\
\hline \# of countries & 97 & 89 & 96 & 97 \\
\hline Country & yes & yes & yes & yes \\
\hline Year & yes & yes & yes & yes \\
\hline F stat & 5.937 & 6.385 & 5.620 & 11.96 \\
\hline Kleibergen-Paap F stat & 12.64 & 17.81 & 10.04 & 33.03 \\
\hline Hansen J stat p-value & 0.283 & 0.172 & 0.259 & 0.219 \\
\hline $\begin{array}{l}* \star * \\
\text { Notes: Robust standard } \\
\text { Noverages used. Log of } s \\
\text { averag } \\
\text { regression. Outliers in } 9 \\
\text { self-employment, defin } \\
\text { percentile, are dropped } \\
\text { world income (using av }\end{array}$ & $\begin{array}{l}\text { o.1 } \\
\text { rors, clustere } \\
\text {-employmen } \\
\text { wth, defined } \\
\text { as countries } \\
\text { he instrumen } \\
\text { ge trade sha }\end{array}$ & $\begin{array}{l}\text { the country } \\
\text { the depender } \\
<-60 \% \text { or }>6 \\
\text { th changes }< \\
\text { in each regres } \\
\text { from } 2000-2 C\end{array}$ & $\begin{array}{l}\text { el, are in brac } \\
\text { ariable for e } \\
\text { 6, are droppe } \\
\text { percentile ar } \\
\text { n are trade-v } \\
\text { ) and oil pric }\end{array}$ & $\begin{array}{l}\text { ets. 5-year } \\
\text { Outliers in } \\
>\text { 99th } \\
\text { ighted } \\
\text { shocks. }\end{array}$ \\
\hline
\end{tabular}

Table Appendix 1. 4. Robustness checks with interaction terms

\begin{tabular}{|c|c|c|c|c|c|}
\hline & \multicolumn{5}{|c|}{ Dependent variable: Self-employment } \\
\hline & (1) & (2) & (3) & (4) & $(6)$ \\
\hline GDP & $\begin{array}{c}-0.698^{* * *} \\
{[0.226]}\end{array}$ & $\begin{array}{c}-0.693^{* * *} \\
{[0.200]}\end{array}$ & $\begin{array}{c}-0.667^{* * *} \\
{[0.218]}\end{array}$ & $\begin{array}{c}-0.698 * * * \\
{[0.218]}\end{array}$ & $\begin{array}{c}-0.705^{* * *} \\
{[0.254]}\end{array}$ \\
\hline GDP * LIC & $\begin{array}{c}0.067 \\
{[0.088]}\end{array}$ & & & & \\
\hline GDP * APD & & $\begin{array}{c}0.223 * \\
{[0.129]}\end{array}$ & & & \\
\hline GDP * EUR & & & $\begin{array}{c}0.097 \\
{[0.106]}\end{array}$ & & \\
\hline $\mathrm{GDP} * \mathrm{WHD}$ & & & & $\begin{array}{c}0.321 * * * \\
{[0.109]}\end{array}$ & \\
\hline GDP * post-95 & & & & & $\begin{array}{c}0.020 \\
{[0.041]} \\
\end{array}$ \\
\hline Observations & 461 & 461 & 461 & 461 & 461 \\
\hline \# of countries & 101 & 101 & 101 & 101 & 101 \\
\hline Country & yes & yes & yes & yes & yes \\
\hline Year & yes & yes & yes & yes & yes \\
\hline F stat & 8.357 & 6.094 & 5.750 & 5.881 & 5.565 \\
\hline Kleibergen-Paap F stat & 13.21 & 15.74 & 16.56 & 13.08 & 13.04 \\
\hline Hansen J stat p-value & 0.255 & 0.494 & 0.200 & 0.200 & 0.236 \\
\hline $\begin{array}{l}{ }^{* *} \mathrm{p}<0.01,{ }^{* *} \mathrm{p}<0.05,{ }^{*} \\
\text { Notes: Robust standard } \\
\text { used. Log of self-emplos } \\
\text { defined as }<-60 \% \text { or }> \\
\text { with changes }<1 \text { st perc } \\
\text { regression are trade-wei } \\
\text { and oil price shocks. }\end{array}$ & $\begin{array}{l}\text { 0.1 } \\
\text { rors, clustere } \\
\text { hent is the } Y \\
\% \text {, are dropp } \\
\text { tile and }>99 \\
\text { hted world in }\end{array}$ & $\begin{array}{l}\text { at the count } \\
\text { riable for ea } \\
\text { d. Outliers ir } \\
\text { percentile, } \\
\text { ome (using a }\end{array}$ & $\begin{array}{l}\text { level, are in } \\
\text { regression. } \\
\text { elf-employn } \\
\text { re dropped. } \\
\text { erage trade }\end{array}$ & $\begin{array}{l}\text { Drackets. 5-ye } \\
\text { Dutliers in gr } \\
\text { ent, defined } \\
\text { he instrumen } \\
\text { hares from } 20\end{array}$ & $\begin{array}{l}\text { averages } \\
\text { wth, } \\
\text { countries } \\
\text { s in each } \\
0-2009)\end{array}$ \\
\hline
\end{tabular}




\section{Appendix 2. Derivations and Model Extension}

\section{Comparative statics derivations}

$$
\begin{gathered}
\partial a^{*} / \partial A=-\frac{1}{A^{2}}[1-T-b(1-p)-C]<0 \\
\partial a^{*} / \partial p=-\frac{b}{A^{2}}[1-T-b(1-p)-C]^{2}<0 \\
\partial a^{*} / \partial T=\partial a^{*} / \partial C=\frac{1}{A}[1-T-b(1-p)-C]^{2}>0
\end{gathered}
$$

and, further,

$$
\partial a^{*} / \partial x=\left[d F\left(a^{*}\right) / d a^{*}\right] *\left[d a^{*} / d x\right]>0
$$

with the first bracketed term being positive and where $x=T, C$, or $p$.

$$
\begin{gathered}
\partial^{2} a^{*} / \partial A \partial T=\partial^{2} a^{*} / \partial A \partial C=-\frac{1}{A^{2}}[1-T-b(1-p)-C]^{2}<0 \\
\partial^{2} a^{*} / \partial A \partial T=\partial^{2} a^{*} / \partial A \partial C=\frac{b}{A^{2}}[1-T-b(1-p)-C]^{2}>0
\end{gathered}
$$

\section{Model extension to account for 'partial' tax evasion}

Let $z_{i}$ denote the fraction of firm i's output that is declared for tax purposes, and $1-z_{i}$ be the fraction of output that is not declared. For simplicity, we now ignore productivity difference across the sectors, $b=1$; and let $T$ denote the tax rate as above.

Then the profit derived from the declared output is $a_{i} A z_{i}(1-T)$. Further, suppose that the probability of detecting activity of non-compliant firms increases with its scope, $p\left(a_{i} A\left(1-z_{i}\right)\right)$, $p^{\prime}, p^{\prime \prime}>0$. Then the expected profit in the compliant sector is $a_{i} A\left(1-z_{i}\right)(1-p)$, and the total expected profit is

$$
a_{i} A z_{i}(1-T)+a_{i} A\left(1-z_{i}\right)(1-p)
$$

Differentiating with respect to $z_{i}$ we obtain at the internal solution:

$$
a_{i} A(1-T)-a_{i} A(1-p)+a_{i} A p^{\prime} a_{i} A=a_{i} A(p-c)+\left[a_{i} A\right]^{2} p^{\prime}=0
$$


or, rearranging the terms, $\left[a_{i} A\right] p^{\prime}+p=T$; and total differentiation reveals that $\frac{\partial z_{i}}{\partial A}>0$, so that the larger is the technological opportunities' set, the larger is the share of output each firm declares for tax purposes.

\section{Appendix 3. Variable Definitions and Descriptive Statistics}

Table Appendix 3. 1. Variables, Definitions and Units

\begin{tabular}{|c|c|}
\hline Variable & Definition \\
\hline Sales reported & Percent of sales reported by an enterprise for tax purposes \\
\hline Labor productivity & Sales in 2002 USD per employee (in logs) \\
\hline $\begin{array}{l}\text { Regional IV for labor } \\
\text { prod. }\end{array}$ & $\begin{array}{l}\text { IV constructed as the simple average of productivity in other regions of } \\
\text { the same country, industry and year }\end{array}$ \\
\hline $\begin{array}{l}\text { International IV for labor } \\
\text { prod. }\end{array}$ & $\begin{array}{l}\text { IV constructed as the average of productivity in the same industry and } \\
\text { year in two other countries in the sample that have a GDP that is at } \\
\text { least } 5 \text { times as large and are located in the same World Bank region } \\
\text { (commodity exporters not matched with non-commodity exporters) }\end{array}$ \\
\hline TFP, LP & Total factor productivity based on Levinsohn and Petrin (2003) (in logs) \\
\hline Age & Age of the establishment (in logs) \\
\hline Exporter & 1 if a firm exports goods or services, 0 otherwise \\
\hline Foreign-owned & 1 if the primary owner is a foreign individual or entity, 0 otherwise \\
\hline Government-owned & $\begin{array}{l}1 \text { if the establishment is government-owned or operates under control } \\
\text { of the government, } 0 \text { otherwise }\end{array}$ \\
\hline Small & 1 if a firm employs fewer than 5 workers, 0 otherwise \\
\hline Perception of tax admin. & $\begin{array}{l}\text { Perception of tax administration as a constraint to doing business (on a } \\
\text { scale from } 1 \text { (least binding) to } 4 \text { (most binding) and normalized by } \\
\text { average constraint perception) }\end{array}$ \\
\hline
\end{tabular}

Table Appendix 3. 2. Descriptive Statistics of IV Baseline Sample

\begin{tabular}{|l|ccccccc|}
\hline Variable & MIN & p25 & p75 & MAX & Average & Std. Dev. & Number \\
\hline Sales reported & 0 & 70 & 100 & 100 & 81.95 & 28.07 & 11,865 \\
Labor productivity & -2.33 & 7.49 & 10.45 & 19.34 & 8.73 & 2.47 & 11,865 \\
Age & 0 & 1.95 & 3.14 & 4.61 & 2.55 & 0.81 & 11,865 \\
Exporter & 0 & 0 & 0 & 1 & 0.20 & 0.40 & 11,865 \\
Foreign-owned & 0 & 0 & 0 & 1 & 0.11 & 0.31 & 11,865 \\
Government-owned & 0 & 0 & 0 & 1 & 0.03 & 0.18 & 11,865 \\
Small & 0 & 0 & 0 & 1 & 0.11 & 0.32 & 11,865 \\
Perception of tax admin. & 0 & 0 & 1.33 & 4 & 0.93 & 0.76 & 11,865 \\
\hline
\end{tabular}




\section{Appendix 4. Regional and International Instrument Construction}

In this Appendix, we provide additional information on the compilation of the regional and international instruments.

Table Appendix 4. 1. Regional Instruments (Main Sample)

\begin{tabular}{|c|c|c|c|}
\hline Year & Country & Region & Percent of observations \\
\hline \multirow{9}{*}{2003} & Cambodia & KHM Phnom Penh & 62.75 \\
\hline & El Salvador & SLV San Salvador & 71.51 \\
\hline & Honduras & HND Tegucigalpa & 24.40 \\
\hline & Kyrgyz Republic & KGZ Bishkek & 44.87 \\
\hline & Lesotho & LSO Maseru & 66.67 \\
\hline & Mali & MLI Bamako & 93.10 \\
\hline & Moldova & MDA Chisinau & 48.31 \\
\hline & Nicaragua & NIC Managua & 43.17 \\
\hline & Tajikistan & TJK Dushanbe & 36.84 \\
\hline \multirow{2}{*}{2004} & Guyana & GUY Georgetown & 23.68 \\
\hline & Sri Lanka & LKA Sri Jayawardenepura Kotte & 33.96 \\
\hline \multirow{24}{*}{2005} & Albania & ALB Tirana & 31.75 \\
\hline & Armenia & ARM Yerevan & 59.34 \\
\hline & Belarus & BLR Minsk & 36.55 \\
\hline & Bosnia and Herzegovina & BIH Sarajevo & 32.14 \\
\hline & Bulgaria & BGR Sofia & 22.47 \\
\hline & Croatia & HRV Zagreb and surroundings & 29.06 \\
\hline & Czech Republic & CZE Praha & 20.31 \\
\hline & Estonia & EST Tallin & 63.33 \\
\hline & North Macedonia & MKD Skopje & 53.62 \\
\hline & Georgia & GEO Tbilisi & 65.88 \\
\hline & Greece & GRC Athens & 38.81 \\
\hline & Hungary & HUN Budapest Central & 32.71 \\
\hline & Ireland & IRL Dublin & 37.28 \\
\hline & Kyrgyz Republic & KGZ Bishkek & 26.81 \\
\hline & Latvia & LVA Riga & 51.32 \\
\hline & Lithuania & LTU Vilnius & 30.89 \\
\hline & Moldova & MDA Chisinau & 35.53 \\
\hline & Portugal & PRT Lisbon & 15.51 \\
\hline & Romania & ROM Bucharest-IIfov & 16.14 \\
\hline & Slovak Republic & SVK Bratislava & 43.53 \\
\hline & Slovenia & SVN Ljubljana & 20.13 \\
\hline & Tajikistan & TJK Dushanbe & 40.99 \\
\hline & Ukraine & UKR Kiev & 13.16 \\
\hline & Uzbekistan & UZB Tashkent \& Tashkentskaja & 30.17 \\
\hline \multirow{14}{*}{2006} & Bolivia & BOL La Paz & 45.94 \\
\hline & Chile & CHL Santiago & 62.69 \\
\hline & Ecuador & ECU Pichincha & 55.05 \\
\hline & El Salvador & SLV San Salvador & 61.32 \\
\hline & Gambia, The & GMB KMC & 85.71 \\
\hline & Guinea & GIN Conakry & 85.95 \\
\hline & Honduras & HND Tegucigalpa & 39.41 \\
\hline & Mauritania & MRT Nouakchott & 87.93 \\
\hline & Nicaragua & NIC Managua & 47.56 \\
\hline & Panama & PAN Ciudad De Panama & 93.79 \\
\hline & Paraguay & PRY Asuncion & 58.17 \\
\hline & Peru & PER Lima & 78.57 \\
\hline & Rwanda & RWA Kigali & 93.10 \\
\hline & Swaziland & SWZ Matsapha & 70.49 \\
\hline
\end{tabular}




\begin{tabular}{|l|lll|}
\hline & Uruguay & URY Montevideo & 75.44 \\
\hline \multirow{2}{*}{2007} & Ghana & GHA Accra-Temin & 59.34 \\
& Mali & MLI Bamako & 62.81 \\
\hline 2009 & Liberia & LBR Montserrado & 66.29 \\
\hline \multirow{2}{*}{2010} & Botswana & BWA Gaborone & 88.68 \\
& Mali & MLI Bamako & 48.89 \\
\hline
\end{tabular}

Notes: The column "Region" either displays the identified (i.e., not rest-of-the country) region or the largest among two identified regions.

Enterprise Surveys from specific countries are either excluded because we were unable to construct a regional instrument or because there was no data from a country that could have been used as an instrument.

We define commodity exporters as countries that export oil, gas, and metals (such as copper, gold, iron, and silver), where these commodities represent a large share of exports (20 percent or more of total exports) or fiscal revenues (IMF, 2015b).

Table Appendix 4. 2. Commodity Country Pairs (IV Baseline Sample)

\begin{tabular}{|c|c|c|c|c|c|}
\hline WB region & Year & Instruments & Instrumented countries & Excluded countries & Commodity Exporter \\
\hline \multirow{3}{*}{$\begin{array}{l}\text { Europe and Central } \\
\text { Asia }\end{array}$} & 2003 & $\begin{array}{l}\text { Poland, } \\
\text { Uzbekistan }\end{array}$ & Kyrgyz Republic, Moldova, Tajikistan & - & No \\
\hline & 2005 & $\begin{array}{l}\text { Germany, } \\
\text { Spain }\end{array}$ & $\begin{array}{l}\text { Albania, Armenia, Belarus, Bosnia and } \\
\text { Herzegovina, Bulgaria, Croatia, Czech } \\
\text { Republic, Estonia, North Macedonia, } \\
\text { Georgia, Hungary, Ireland, Kyrgyz } \\
\text { Republic, Latvia, Lithuania, Moldova, } \\
\text { Portugal, Romania, Slovak Republic, } \\
\text { Slovenia, Tajikistan, Uzbekistan }\end{array}$ & \multirow[t]{2}{*}{-} & \multirow[t]{2}{*}{ No } \\
\hline & & Germany & Greece, Ukraine & & \\
\hline \multirow{5}{*}{$\begin{array}{l}\text { Latin America and } \\
\text { Caribbean }\end{array}$} & 2003 & Brazil & Honduras, Nicaragua, El Salvador & Guatemala & No \\
\hline & 2004 & Chile & Guyana & - & Yes \\
\hline & \multirow{3}{*}{2006} & Argentina & $\begin{array}{l}\text { Honduras, Nicaragua, Panama, Paraguay, } \\
\text { El Salvador, Uruguay }\end{array}$ & Guatemala & No \\
\hline & & $\begin{array}{l}\text { Mexico, } \\
\text { Venezuela }\end{array}$ & Bolivia & \multirow[t]{2}{*}{-} & \multirow[t]{2}{*}{ Yes } \\
\hline & & Mexico & Chile, Ecuador, Peru & & \\
\hline \multirow{2}{*}{$\begin{array}{l}\text { South, East Asia } \\
\text { and Pacific }\end{array}$} & 2003 & $\begin{array}{l}\text { China, } \\
\text { Philippines }\end{array}$ & Cambodia & - & No \\
\hline & 2004 & Thailand & Sri Lanka & - & No \\
\hline \multirow{8}{*}{ Sub-Saharan Africa } & \multirow[t]{2}{*}{2003} & $\begin{array}{l}\text { Kenya, } \\
\text { Tanzania }\end{array}$ & Lesotho & - & No \\
\hline & & South Africa & Mali & - & Yes \\
\hline & \multirow{3}{*}{2006} & $\begin{array}{l}\text { Tanzania, } \\
\text { Uganda }\end{array}$ & The Gambia & \multirow[t]{2}{*}{-} & \multirow[t]{2}{*}{ No } \\
\hline & & Tanzania & Rwanda, Swaziland & & \\
\hline & & Angola & Guinea, Mauritania & Republic of Congo & Yes \\
\hline & 2007 & $\begin{array}{l}\text { Nigeria, } \\
\text { South Africa }\end{array}$ & Ghana, Mali & - & Yes \\
\hline & 2009 & $\begin{array}{l}\text { Burkina Faso, } \\
\text { Madagascar }\end{array}$ & Liberia & - & No \\
\hline & 2010 & Angola & Botswana, Mali & Republic of Congo & Yes \\
\hline
\end{tabular}

Notes: GDP of the country used as an instrument must be at least 5 times larger than that of an instrumented country. 


\section{Appendix 5. First Stage Regressions}

Table Appendix 5. 1. First Stage of Table 2

Dependent variable: Labor productivity [log]

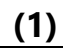

(2)

(3)

(4)

\begin{tabular}{|c|c|c|c|c|}
\hline $\begin{array}{l}\text { Regional IV for labor } \\
\text { prod. [log] }\end{array}$ & $\begin{array}{c}0.179 * * * \\
{[0.067]}\end{array}$ & $\begin{array}{l}0.175^{* *} \\
{[0.073]}\end{array}$ & $\begin{array}{c}0.179 * * * \\
{[0.043]}\end{array}$ & $\begin{array}{c}0.174 * * * \\
{[0.066]}\end{array}$ \\
\hline International IV for & $0.250 * * *$ & $0.151 * * *$ & $0.250 * * *$ & $0.249 * * *$ \\
\hline labor prod. [log] & {$[0.042]$} & {$[0.030]$} & {$[0.050]$} & {$[0.040]$} \\
\hline & $0.053^{* *}$ & $0.054^{* *}$ & $0.053^{* * *}$ & \\
\hline Age от Tirm [log] & {$[0.024]$} & {$[0.024]$} & {$[0.019]$} & \\
\hline & $0.340 * * *$ & $0.345^{* * *}$ & $0.340 * * *$ & $0.341 * * *$ \\
\hline Exporter [dummy] & {$[0.073]$} & {$[0.070]$} & {$[0.046]$} & {$[0.070]$} \\
\hline Foreign-owned & $0.428 * * *$ & $0.401 * * *$ & $0.428 * * *$ & $0.419 * * *$ \\
\hline [dummy] & {$[0.086]$} & {$[0.082]$} & {$[0.061]$} & {$[0.082]$} \\
\hline Government-owned & -0.050 & -0.043 & -0.050 & -0.037 \\
\hline [dummy] & [0.047] & {$[0.044]$} & {$[0.056]$} & {$[0.045]$} \\
\hline Small [dummv] & 0.079 & 0.077 & 0.079 & 0.079 \\
\hline smail [aummy] & [0.054] & {$[0.055]$} & [0.054] & [0.055] \\
\hline Perception of tax & $0.048 * * *$ & & $0.048^{* * *}$ & $0.048 * * *$ \\
\hline admin. & {$[0.015]$} & & {$[0.014]$} & [0.015] \\
\hline Observations & 11,865 & 13,208 & 11,865 & 11,869 \\
\hline \# of firms: & 11,741 & 13,056 & 11,741 & 11,745 \\
\hline \# of countries: & 47 & 47 & 47 & 47 \\
\hline \# of industries: & 18 & 18 & 18 & 18 \\
\hline Region*Year & yes & yes & yes & yes \\
\hline Region*Industry & yes & yes & yes & yes \\
\hline Age & no & no & no & yes \\
\hline
\end{tabular}

Table Appendix 5. 2. First Stage of Table 3

\begin{tabular}{|c|c|c|c|c|}
\hline & \multicolumn{4}{|c|}{ Dependent variable: Labor productivity [log] } \\
\hline & (1) & (2) & (3) & (4) \\
\hline $\begin{array}{l}\text { Regional IV for labor } \\
\text { prod. [log] }\end{array}$ & $\begin{array}{c}0.185^{* * *} \\
{[0.031]}\end{array}$ & $\begin{array}{c}0.181 * * * \\
{[0.067]}\end{array}$ & $\begin{array}{c}0.187^{* * *} \\
{[0.070]}\end{array}$ & $\begin{array}{c}0.208 * * * \\
{[0.078]}\end{array}$ \\
\hline $\begin{array}{l}\text { International IV for } \\
\text { labor prod. [log] }\end{array}$ & $\begin{array}{c}0.130 \\
{[0.091]}\end{array}$ & $\begin{array}{c}0.251 * * * \\
{[0.042]}\end{array}$ & $\begin{array}{c}0.255^{* * *} \\
{[0.044]}\end{array}$ & $\begin{array}{c}0.254 * * * \\
{[0.042]}\end{array}$ \\
\hline Age of firm [log] & $\begin{array}{c}0.005 \\
{[0.049]}\end{array}$ & $\begin{array}{l}0.057^{* *} \\
{[0.025]}\end{array}$ & $\begin{array}{l}0.062 * * \\
{[0.025]}\end{array}$ & $\begin{array}{l}0.050 * * \\
{[0.025]}\end{array}$ \\
\hline Exporter [dummy] & $\begin{array}{c}0.408 * * * \\
{[0.058]}\end{array}$ & $\begin{array}{c}0.365^{* * *} \\
{[0.081]}\end{array}$ & $\begin{array}{c}0.366 * * * \\
{[0.076]}\end{array}$ & $\begin{array}{c}0.365^{* * *} \\
{[0.075]}\end{array}$ \\
\hline $\begin{array}{l}\text { Foreign-owned } \\
\text { [dummy] }\end{array}$ & $\begin{array}{c}0.446 * * * \\
{[0.073]}\end{array}$ & $\begin{array}{c}0.486 * * * \\
{[0.083]}\end{array}$ & $\begin{array}{c}0.540 * * * \\
{[0.089]}\end{array}$ & $\begin{array}{c}0.465^{* * *} \\
{[0.097]}\end{array}$ \\
\hline $\begin{array}{l}\text { Government-owned } \\
\text { [dummy] }\end{array}$ & $\begin{array}{c}0.852 \\
{[0.553]}\end{array}$ & $\begin{array}{l}-0.040 \\
{[0.059]}\end{array}$ & $\begin{array}{c}0.011 \\
{[0.123]}\end{array}$ & $\begin{array}{l}-0.063 \\
{[0.051]}\end{array}$ \\
\hline Small [dummy] & $\begin{array}{c}0.092 \\
{[0.058]}\end{array}$ & $\begin{array}{c}0.098 \\
{[0.061]}\end{array}$ & $\begin{array}{c}0.144 \\
{[0.103]}\end{array}$ & $\begin{array}{c}0.060 \\
{[0.051]}\end{array}$ \\
\hline $\begin{array}{l}\text { Perception of tax } \\
\text { admin. }\end{array}$ & $\begin{array}{l}-0.064 \\
{[0.084]}\end{array}$ & $\begin{array}{c}0.048 * * * \\
{[0.017]}\end{array}$ & $\begin{array}{c}0.068 * * * \\
{[0.020]}\end{array}$ & $\begin{array}{c}0.053 * * * \\
{[0.015]}\end{array}$ \\
\hline Observations & 13,618 & 9,980 & 13,937 & 10,198 \\
\hline \# of firms: & 13,464 & 9,856 & 13,725 & 10,079 \\
\hline \# of countries: & 50 & 38 & 54 & 46 \\
\hline \# of industries: & 18 & 18 & 20 & 17 \\
\hline Region*Year & yes & yes & yes & yes \\
\hline Region*Industry & yes & yes & yes & yes \\
\hline
\end{tabular}

*** $p<0.01,{ }^{* *} p<0.05,{ }^{*} p<0.1$

Notes: Errors in brackets clustered at the region and industry-year level. 